\title{
Forecasting the World's Development Trend and the Preparation of Capacity for Vietnamese Cadres and Civil Servants to Adapt to the New Conditions
}

\author{
To Hoang Linh ${ }^{* 1}$, To Nai $\mathrm{Nao}^{2}$, Ngo Van hung ${ }^{3}$ \\ ${ }^{1}$ Tuyen Quang City People's Committee, Tuyen Quang, Viet Nam. \\ ${ }^{2}$ Propaganda Department of Soc Trang Provincial Party Committee, Soc Trang, Viet Nam. \\ ${ }^{3} \mathrm{Ha}$ Noi University of Home Affairs, Ha Noi, Viet Nam.
}

How to cite this paper: To Hoang Linh, To Nai Nao, and Ngo Van hung. (2020) Forecasting the World's Development Trend and the Preparation of Capacity for Vietnamese Cadres and Civil Servants to Adapt to the New Conditions. International Journal of Humanities, Arts and Social Science, 4(1), 1-7.

DOI: $10.26855 /$ jhass.2020.01.001

Received: March 8, 2020

Accepted: March 29, 2020

Published: April 3, 2020

*Corresponding author: To Hoang Linh, Tuyen Quang City People's Committee, Tuyen Quang, Viet Nam.

Email:

tohoanglinhtqvn@gmail.com

\begin{abstract}
Today, the complex transformation of the world situation requires each country to have a new mindset, to make maximum use of available resources, to promote strengths, to repel risks, which facilitate motivation for integration and development. The trend of the new situation shows that the development of Viet Nam, through the administrative apparatus, is directly or indirectly determined by the human factor. In particular, when we build a strong and high-quality public servant team - this will be the key decision towards the operational efficiency of the administrative apparatus and vision for the country's development.

Based on official documents and studies, the author proposes "Forecasting the development trend of the world and the preparation of capacity for Vietnamese cadres and civil servants to adapt to the new conditions". Accordingly, the article reviews and gives basic predictions about the world, regional and domestic situation in accordance with the trend of development. From that basis, the author assesses the current situation of Vietnamese cadres' and civil servants' capacity and proposes solutions essentially for addressing 3 factors: knowledge, skills, and qualities, attitudes, which are the factors that constitute the necessary capacity of Vietnamese cadres and civil servants to adapt to the new conditions.
\end{abstract}

Keywords

Capacity, Cadres, Civil Servants

\section{Introduction}

Today, the world is changing deeply in many aspects. Accordingly, opportunities will be important factors, a new wind creating breakthroughs for nations; At the same time, the risks and fluctuations of the world are also a great challenge for all nations. The complex transformation of the world situation requires each country to have new thinking, to make maximum use of available resources, to promote its strengths, to repel risks, which facilitate motivation for integration and development. The trend of the new situation shows that the development of Viet Nam, through the administrative apparatus, is directly or indirectly determined by the human factor. In 
particular, when we build a strong and high-quality public servant team - this will be the key decision towards the operational efficiency of the administrative apparatus and vision for the country's development.

For Vietnam, in the process of integration and development, along with the changes of the new trend, building a sustainable administrative apparatus based on a team of qualified, enthusiastic and capable cadres and civil servants is one of five important goals of the State Administration Reform Program for the period of 2011 - 2020 : "Building a contingent of qualified and capable cadres, meeting the requirements of serving people and the development of the country". From the State Administration Reform Program, it is required to equip the contingent of cadres and civil servants with the necessary competencies, professionalism, responsibility, dynamism, transparency and efficiency, to take a leap way to anticipate the country's development.

\section{The World and Regional Situation}

In the past 20 years, the situation in the world and in the region has experienced lots of rapid, complicated and unpredictable happenings; at the same time not only facilitating opportunities and advantages but also posing severe difficulties and challenges, affecting many aspects of our country. While the world situation has changed greatly in a clearer mode, from a uni-polar world into a multi-polar world; trend of globalization, link between countries is getting stronger and stronger; major countries have adjusted their strategies and the competitiveness has become more and more significantly, changing international relations. Prolonged regional and global financial crises have directly and indirectly affected the socioeconomic development of many countries around the world, including Vietnam. At the same time, regional wars, armed clashes, race conflicts, ethnic conflicts, religion and terrorism, refugees take place in many parts of the world. The gap between the rich and the poor between countries and within each country is wider. Non-traditional security issues has increasingly affected the international community; instability due to disputes, trade tensions; climate change are getting more and more complicated and have increasingly badly affected globally, of which Vietnam is one of the countries suffering direct affection. In particular, the development of the knowledge economy and the science-technology revolution, especially the industrial revolution 4.0, is merging the real and virtual world. Thanks to technologies such as the Internet of Things (IoT), artificial intelligence (AI), virtual reality (VR) ... the real world is gradually becoming a digital world, which creates both opportunities and challenges for all developing countries, especially Vietnam.

The regional situation has many changes and complicatedly new developments affecting our country, especially the formation and development of the ASEAN and the regional financial crisis; situation of tensions and disputes over borders and islands between nations takes place more and more complicatedly.

\section{Predictions on the World Development Trend}

Firstly, the situation in the world and the Asia-Pacific region in 2018 changed quickly and complicatedly due to the adjustment of policies of the US, China and major countries. International security is complicated in both traditional and non-traditional aspects. Therefore, the global and regional situation has been and will continue to follow complicated and volatile development trends. However, peace, cooperation and development are still the mainstream and urgent demands of countries around the world. It can be affirmed that all countries desire to live in an environment of peace, friendship and cooperation. The facts show that some areas still have complexities, leading to permanent anxiety, insecurity towards people's life, holding back and running counter to the country's development. Therefore, the main trend in the future is the efforts of all countries who build a peaceful and stable environment to ensure people's life and facilitate a driving force for the development of the country.

Secondly, economic matter will be the core issue of nations. The world economy maintains a pretty good growth momentum but carries many potential risks due to the increasing protectionism and trade friction among major countries. In the coming journey, the economy of the world and the region will be in the stage of recovery and development associated with the hidden, and unpredictable factors. Economic globalization facilitates opportunities but still brings intertwining the elements of inequality, difficulties and challenges to all nations, especially developing countries. Since then, the requirements towards all nations are to have the right path, strategy and high-quality labor resources, to solve the problem of economic development. Notably, the multilateral system, especially multilateral trade, is facing a big challenge, requiring adjustment of the "rules of the game" in accordance with the change in correlation of new forces. Under the impact of the 4th industrial revolution, new forms of economy have appeared: shared economy, cyber economy, recirculation economy, 
opening up development opportunities but also increasing the risk of out of date further in developing countries, including Vietnam.

Thirdly, the achievements of the 4.0 industrial revolution have been and will bring many opportunities to all countries in improving their technological level, production capacity and competitiveness in the global value chain; bringing major changes in the sustainable business model and opportunities for innovative startups; Bringing potential to developing countries. In particular, Vietnam can be helped to shorten the process of industrialization by taking leaps, bounds to develop higher technology. However, without the right approach and keeping pace with the world's pace of development, all countries will face the risk of further technological lag, low redundancy of unskilled labor and inequality in society.

Besides, the connection and cohesion in the era of Industrial Revolution 4.0 lead to the issues of soft borders, soft power, cybersecurity issues and non-traditional security; natural disasters, abnormal weather and the risk of food insecurity, water security, increased environmental degradation; drought, soil erosion, floods in Viet Nam, Laos, Philippines, China, Japan; earthquakes in Taiwan, China and Japan. Climate change causes heat, forest fires in Greece, Sweden, the UK, Canada, and the US; volcanic eruptions caused serious damage to people and properties and left many consequences for socioeconomic development. In particular, new non-traditional security issues such as cyber attacks, cybersecurity, universe's space exploitation and utilization have become a top concern of many countries. Terrorism tends to expand, causing many attacks such as those in Indonesia, the Philippines ... which requires proactive response and good control to ensure sovereignty, security, looking towards to building administrative apparatus serving the people and the country effectively.

\section{Problems Posed to Viet Nam}

\subsection{Domestic situations}

From 1997 up to now, our people's renovation, construction and defense towards the country have made great strides and obtained historic achievements. The country continues the process of transition from the dictatorship of the proletariat into the construction of a socialist legal State of the people, by the people, for the people and to build a socialist democracy; from being besieged, isolated and embargoed into active and intensive international integration; from a centrally planned and subsidized economy into a socialist-oriented market economy; which gradually resolve the harmonious relationship between the State, the market and society. The construction, reorganization of the Party and the construction of the political system have had many positive changes and achieved important initial results. Our economy has achieved a good growth rate in many years, highest in 2017, reaching $6.81 \%$; potential and size of the economy are increasing, foreign exchange reserves reach over 52 billion USD; our country came out of the socio-economic crisis in 2000 and became a middle-income country by 2010 ; national industrialization and modernization has been increasingly promoted comprehensively and synchronously. The process of comprehensive renovation of the country has stepped up and increasingly deepened; maintaining socio-political stability; national defense and security are strengthened; international integration is increasingly extensive; people's material and spiritual life has improved markedly; Foreign relations are expanded, our country's prestige in the international arena is increasingly advanced. Never before has our country had such an opportunity and status.

However, with the requirements and tasks of the new period, the country still faces many difficulties and limitations, weaknesses and shortcomings: The organizational structure of the political system is still cumbersome with multi-levels; functions and tasks are overlapping, duplicated with low effeciency and performance; activities of Communist Party and political system building challenge limitation, shortcomings and inadequacies. Economic development is not really sustainable; frequent expenditure is increasing and is at a high level (accounting for nearly $65 \%$ of total state budget expenditure); bad debt is still too much and public debt is high; The quality, efficiency, labor productivity and competitiveness of the economy are still low. Several aspects of international integration have not yet been active, the efficiency is not high. Depression of political ideology, morality, lifestyle and expressions of "self-evolution", "self-transformation" in a part of cadres and party members, including leading and managing officials reasons at all levels have not been fought to prevent or repel; bureaucracy, corruption, wastefulness, group interests, running for office, running power ... take place at many levels and sectors. If the above-mentioned shortcomings and weaknesses are not prevented and overcome in time, they will erode the beliefs of officials, communist party members and people towards the Communist Party and the State; threatening 
the survival of the regime. Many new and complicated issues arise, especially social and social management issues that have not been effectively addressed, so they have potential factors and risks that may cause socio-political instability. Meanwhile, the resistance of hostile forces, reactionary organizations and bad elements towards our Party and State with the "Strategy of peaceful evolution" has become more and more sophisticated and drastic. The four threats that the Midterm Conference VII of the Party Congress (January 1994) identified, so far have no longer been a risk, but have become significant challenges in practice, especially the depression and the lag situation of the cadres, communist party members, which has become more and more serious in comparision with those in regional and global countries.

\subsection{Situation of cadres' and civil servants' capacity}

As of March 2017, the total number of officials, public servants and employees in the political system is: 2,726,917 people (611,069 officials and civil servants people; 1,983,981 officials, 131,867 people working under contracts in accordance with Decree 68-ND/CP dated 17/11/2000 of the Government on the implementation of the contract regime of some types of work in state administrative agencies, non-business units), of whom there were more than 81,000 leading cadres with working positions as division officials of district level to deputy ministers. Thus, by 2017, after 20 years of implementing the Staff Strategy, the number of cadres, civil servants and public employees increased more than 2 times, while the national population increased by nearly 1.3 times and the average income per capita people increased nearly 4 times compared to that of 1997 (In 1997, there were 1,351,900 cadres, civil servants and public employees, the population was about 77 million people, the average income was nearly 400 USD/person/year. In 2017, there were 2,726,917 cadres, civil servants, the population was about 92 million and the average income was 2,350 USD/person/year).

The contingent of cadres and civil servants has rapidly developed in terms of quantity and quality; The structure of age, sex, occupation and field of work is more balanced and reasonable. The number of staff with university and post-graduate qualifications have increased rapidly. The qualifications and knowledge of political theory, economic management, state management, professional skills, foreign languages, etc, and the capacity and practical experience of the staff have been improved. Cadres and civil servants are plentifully planned for higher positions, ensuring the working position inheriting transition between generations.

However, in practice, Viet Nam's cadres and civil servants are crowded but not qualified, the quality is uneven, lack the connection between levels, sectors and a number of cadres and civil servants have not met the requirements of the new era; situation of redundancy and lack of staff have existed in many places; There is a shortage of leading offcials, good managers, leading experts in various fields; lots of cadres, including leading managers at all levels and a number of leading officials from district levels, have had limited competence and have been unable to fulfil their assigned duties; Thinking, ability to adapt to market economy, international integration is still slow; Leadership, steering, advisory, and implementation capacity is still limited. The rate of young cadres, female officials and ethnic-minority officials have not met the requirements; staff structure between industries, fields and regions is not very reasonable. A number of cadres with fading ideals, unstable political courage, limited revolutionary life-force; have not been exemplary in implementing the communist Party's policies, the State law. Some leading officials and managers at all levels, including those of district levels upwards, are still bureaucratic with masterful and impractical working style towards civilian; failing to fulfill their duties in front of the Party and the civilian; corruption, wastefulness, abuse of positions and powers to conduct corruption for individual himself/herself and other negative matters performed by the civil staff, which causes annoyance in social public opinion.

\subsection{Necessary capabilities for Vietnamese cadres and civil servants to adapt to the new conditions}

Competence is all about the psychological characteristics of people with a certain form of professional activity that have been formed previously. Human power is not determined by its brain activity, but first of all, by the historical development level that the mankind has achieved. In that sense, the human capacity is inseparable from the social labor organization and the education system adapting to that organization.

Competency, therefore, is understood as the ability to use human resources, potentials such as knowledge, skills and other qualities to achieve specific goals under a defined condition. Accordingly, the capacity of the contingent of cadres and civil servants is the ability of cadres and civil servants to use knowledge, skills and qualities, 
attitudes to handle a situation, a specific task in a defined environment with the best results. The capacity of cadres and civil servants is not an invariant capacity, used in all circumstances and environments. At a certain time or environment, the capacity is displayed and effective, but at another point of time, a different type of capacity is needed. Or in each period, each situation, different environment, different capacity requirements are imposed. The capacity of cadres and civil servants is always associated with the overall purpose, with the development strategy of the organization and must be associated with specific fields and conditions.

The strong development of regional and global countries; especially Viet Nam's practical international integration process, getting more and more significantly, shows that in order to ensure successful administrative reform to create a breakthrough for national development, it is important to have a contingent of cadres and civil servants in the administrative apparatus with full qualification, capability and ethnics in serving civilian, which poses an urgent need to equip the necessary capabilities for the contingent of cadres and civil servants to suit the development and requirements of the era.

The first, regarding professional knowledge.

The contingent of officials and public employees who directly implement policies and plans of agencies and organizations; national goals; carry out communications (exchanging, receiving information, ...) among state agencies and with enterprises and civilian. Therefore, cadres and civil servants must be paid attention to in training and retraining of professional knowledge, professional skills, sense of responsibility and a sense of service to the people. Accordingly, public servants working in any certain field, necessarily have a deep professional understanding of that field. This is an important requirement: to overcome non-specific position arrangement of cadres and civil servants without professional knowledge as those previously happened. Along with professional knowledge, cadres and civil servants must have broad knowledge, comprehensive socio-political understanding in order to deal flexibly with the fluctuations of the situation. It is knowledge of the law; market economy; international economics and international relations; development trends of the field in which we operate; knowledge of culture, society, history; knowledge, experience, ... specifically, the level of education and expertise (through targets of education level, disciplines to have been trained, forms of training, ranks of civil servants ...)

Along with professional knowledge and skills, the contingent of civil servants must constantly improve their foreign language and informatics skills, be able to apply the advances of science and technology into supporting work handling with better efficiency, especially, we have to pay special attention to training ethnic minority languages for the contingent of cadres and civil servants working in localities with a large number of ethnic minority people. On the basis of sustainable professional knowledge, the staff will help the staff to analyze and solve situation problems, detect challenges, opportunities, threats and propose solutions to take advantage of opportunities and resources to address critical issues. To do that, we need to:

Firstly, we have to develop a national program on training and re-training cadres and civil servants in terms of both professional qualifications and political theory, of which, the training and retraining program must ensure the link between theory and practice, specially paying attention on the ability to practice and connect with other countries to apply theoretical knowledge into practice, acquiring and promoting positive experiences of other countries. At the same time, we have to ensure the system of facilities, equipment, schools and classes for learning and practicing, and lecturers sufficiently in terms of quantity and quality for training and retraining.

Secondly, we have to promote the ability to self-study and self-forge; self-training on the spot, supporting each other in the process of assigning, assigning, inspecting and supervising officials and public employees, which are important contents to build a sensitive and flexible team of cadres and civil servants in handling assigned tasks.

Thirdly, we must have a policy regime, reasonable remuneration for cadres and civil servants so that they have peace of mind to work, wholeheartedly devote to their work, do not violate professional ethnics, avoid negative phenomena.

Fourthly, we have to implement the reward regime timely and reasonably, associated with strict sanctions facilitates a positive momentum and sets a timely example for officials and public employees in the performance of official duties.

The second, regarding the operating organization skills.

Currently, besides the system of diplomas and certificates according to the prescribed standards, operating organization skills, practical experience are those a number of our cadres and civil servants lack and are not good at, especially skills of handling important events. Many cadres and civil servants work very hard with very strict self-requirements, but when they faced serious challenges, they have no opinion with hope for peace; Thinking, 
working skills are also this thinking, only hope for peace without fighting spirit. Therefore, the requirement to be meet is to promote the intensity of selecting cadres and civil servants with sufficient operating and management skills in leading and managing positions, and at the same time let the cadres and civil servants without practical experience and above mentioned skills be trained in a challenging environment, to improve the inherent experience and skills.

It can be said that the contingent of cadres and civil servants with management skills are considered as the brain, the head of the whole apparatus. Because, with their skills, they can perform their duties in actions in specific aspects from their knowlege such as organizational and time management skills, influence skills, mastering skills, solving skills, situation assessing and forecasting skills, especially strategy forecasting skills. In particular, the leading staff of district level upwards have a very important and heavy task of advising the Party, the State, the Government and other ministries, departments and agencies on appropriate strategies and policies. Therefore, this team must proactively capture and assess information properly, in accordance with the practical situation. From there, they can properly forecast the international, regional, and domestic situation and circumtances in accordance with reality.

Decree No. 18/2010 / ND-CP dated 05/32010 of the Government on training and retraining cadres and civil servants emphasizes: "Training and retraining according to job positions is for the sake of equipping and updating knowledge, skills and methods necessary to perform assigned work well". Therefore, in order for cadres and civil servants to gain necessary skills, this team must have a long-term vision, strategic thinking and scientific forecasting ability, keen to identify challenges and capture opportunities. Predictive ability is not necessarily innate, a priory, but it is the result of a basic training process, especially the methods and data needed for forecasting. The quick and flexible ability of staff to forecast when circumstances change bases on the principle of "taking invariant, responding to all variables".

In fact, in Viet Nam, there have not been many facilities for training and retraining skills necessary in handling work, professional handling, especially training and retraining of organizational skills, operating, leadership skills, management. Therefore, this is a matter that needs attention of all levels and sectors, especially the Education and Training sector, in which various skill training forms should be diversified for cadres and civil servants, especially officials and public employees in charge of leadership and management.

Thirdly, regarding quality and attitude, which is an important standard for officials and public servants. This team must be wholeheartedly in working duties, for the sake of serving the state, and act as servants of people, so, this team must be honest with pure revolutionary ethics, and the right conduct in performing public duties.

Revolutionary ethics is the root of cadres and civil servants as an important content of political and ethical qualities. According to President Ho Chi Minh: "Ethnics is revolutionary morality, which is a very important root. Without revolutionary ethics, having talent is useless". In particular, in the face of complicated evolution of social, domestic and international life, the training of revolutionary morality, quality and standard attitudes must be attached to specific actions which are extremely important requirements of cadres and civil servants at all levels. On the basis of a pure quality and attitude, cadres and civil servants must struggle without mercy with individualism, opportunity, pragmatism, corruption and social evils badly effecting the reputation and prestige of the Party, State and our regime.

The world today is a dynamic world, together with the effects of science and technology, which has made lots of changes day by day. Therefore, improving the quality of human resources, especially the contingent of cadres and civil servants in the political system, will make an important contribution to help Viet Nam accelerate the rapid and strong development of renovation, looking forward to a state administrative apparatus which is democratically, purely, modernly, effectively and efficiently developed.

\section{References}

Report of Foresight 2020(2016), Economic, industry and corporate trends, British Economic Intelligence Unit (EIU)

Central Organizing Committee, Ho Chi Minh National Academy of Politics, Communist Review (2018), On cadres and cadres activities- excerpts of speeches and articles of the General Secretary of the Executive Committee Party Central Committee, the Truth National Politics Publishing House

Central Propaganda Department (2018), Research document of Seventh Conference documents of the 12th Party Central Committee (Used for key officials and rapporteur), the Truth National Politics Publishing House, Hanoi. 
Ministry of Politics, Resolution No. 22-NQ/TW dated 10-4-2013 on international integration.

Viet Nam Communist Party (2016), Document of the 12th National Delegation Congress, Office of the Party Central Committee.

The Communist Party of Viet Nam $(2017,2018)$, The 5th, 6th and 7th Conference Documents of the 12th Central Committee of the Communist Party, Office of the Party Central Committee.

Prof. Dr. Vu Van Hien (Editor - 2007), Building a team of leaders and managers to meet the requirements of national industrialization and modernization, Publishing House of National Politics

Tham Vinh Hoa, Ngo Quoc Dieu (Editors - 1996), Nguyen Nhu Diem (translator), Respect for intellectuals, respect for talents - a great successive plan to revive the country, Publishing House of National Politics

Janice Tay \& Ronald Kow (Selection - 2016), Nguyen Phan Nam An (translator), LKY on management - Lee Kuan Yew's discussion on management, Youth Publishing House.

Trinh Cu, PhD. Nguyen Duy Hung, Assoc Prof. PhD. Le Van Yen (2009), Experience in building a contingent of officials in China, Publishing House of National Politics

Law on Public Officials, No. 22/2008 / QH12 (2028), Publishing House of National Politics

Decree 101/2017 / ND-CP, dated 01/92017 of the Government on training and retraining cadres, civil servants and public employees.

Assoc Prof. PhD. Bui Dinh Phong (2006), Ho Chi Minh Thought on cadres and cadre activities, Labor Publishing House.

Prof., PhD. Phung Huu Phu, GS, PhD. Le Huu Nghia, Prof. PhD. Vu Van Hien, Assoc Prof. PhD Nguyen Viet Thong (Co-Editors 2016): Some theoretical and practical issues on socialism and the path to socialism in Viet Nam through 30 years of renovation, the Truth National Politics Publishing House, Hanoi

PhD. Thang Van Phuc, PhD. Nguyen Minh Phuong (Co-Editors - 2005), Theoretical and practical basis for building a contingent of civil servants, Publishing House of National Politics*

Truong Tan Sang (2016), Taking advantage of opportunities, overcoming challenges, continuing comprehensive innovation, take the country forward, the Truth National Politics Publishing House

Thomas J. Christensen (Translators: Nguy Hai An, Vu Tu Linh, Nguyen The Phuong, Nguyen Kim Phung - 2017), The rise of China - Shaping options for an emerging power, the Truth National Politics Publishing House

Prof. PhD. Nguyen Phu Trong, Prof. PhD. Tran Xuan Sam (Co-Editors - 2001), Scientific arguments for improving the quality of civil staff in the period of accelerating industrialization and modernization of the country, Publishing House of National Politics

Assoc Prof. PhD. Nguyen Minh Tuan (Editor - 2017), Renewing the assessment and employment of cadres, Publishing House of Political Theories

Philosophy dictionary, Viet Namese translations with corrections and additions, Progress Publishing and Truth Publishing House, 1986, page 379 . 